\title{
ANALISIS DAYA SAING IKAN TUNA DI PROVINSI GORONTALO
}

\author{
Muhammad Rizq Gobel ${ }^{*} 1$ ), Mahludin Baruwadi ${ }^{2)}$, Asda Rauf ${ }^{2)}$ \\ 1) Jurusan Agribinsis Fakultas Pertanian Universitas Negeri Gorontalo \\ 2) Fakultas Pertanian Universitas Negeri Gorontalo \\ *) E-mail Penulis Korespondensi: qiqigobel@gmail.com
}

\begin{abstract}
ABSTRAK
Penelitian ini bertujuan untuk: 1) mengetahui kecendrungan produksi dan perdagangan ikan tuna; 2) menganalisis daya saing ikan tuna; dan 3) menganalisis strategi pengembangan daya saing ikan tuna. Metode penelitian yang digunakan adalah metode dengan survei primer dan sekunder. Metode analisis yang digunakan dalam penelitian ini adalah metode kuantitatif dan kualitatif. Metode kuantitatif menggunakan analisis RCA dan untuk kualitatif menggunakan analisis tren dan analisis SWOT. Hasil penelitian yang diperoleh adalah 1) perkembangan produksi ikan tuna mengalami fluktuasi, dimana produksi ikan tuna tidak stabil dan selalu berbeda angka produksi tiap tahunnya. 2) Daya saing ikan tuna Provinsi Gorontalo memiliki keunggulan karena hasil perhitungan RCA mendapatkan lebih dari 1, artinya bahwa ikan tuna Provinsi Gorontalo memiliki daya saing yang tinggi di pasar nasional. 3) Analisis SWOT berada di kuadran 1 yaitu strategi agresif. Strategi yang situasinya mendukung secara agresif dan sangat baik karena adanya kekuatan yang dimanfaatkan untuk meraih peluang yang menguntungkan.
\end{abstract}

Kata kunci: Ikan Tuna; Daya Saing; Strategi Pengembangan

\section{PENDAHULUAN}

Indonesia dikenal sebagai Negara dengan kekayaan keanekaragaman hayati laut terbesar di dunia, karena memiliki ekosistem laut dan pesisir yang khas seperti hutan mangrove, terumbu karang (coral reefs), dan padang lamun (sea grass beds) (Darsono, 1999: 2). Menurut Daryanto (2007: 11), sumberdaya pada sektor perikanan merupakan salah satu sumberdaya yang penting bagi hajat hidup masyarakat dan memiliki potensi dijadikan sebagai penggerak utama (prime mover) ekonomi nasional. Akan tetapi, rendahnya pemanfaatan potensi sumber daya kelautan yang sedemikian besar, terutama disebabkan oleh sumber daya manusia dan teknologi yang belum mendukung pengembangan sektor tersebut (Wahyuni, 2011: 9). Kemampuan suatu industri/perusahaan/sektor untuk menarik investasi dan sumberdaya lainnya untuk perdagangannya di pasar global, masih berusaha untuk mendapatkan paling tidak peluang biaya sumberdaya yang mendukung (Johan van Rooyen \& Johann Boonzaaier, 2016: 4).

Letak Provinsi Gorontalo sangatlah strategis, karena diapit oleh dua perairan, yaitu Teluk Gorontalo atau yang lebih dikenal dengan nama Teluk Tomini di sebelah Selatan dan Laut Sulawesi di sebelah Utara. Dalam catatan sejarah maritim Nusantara, Laut Sulawesi menjadi penting karena merupakan jalur pelayaran dari pulau Sulawesi menuju Filipina yang juga melalui jalur wilayah perairan Kesultanan Sulu di sebelah Timur dari Negara Malaysia (DKP, 2014). Provinsi Gorontalo memiliki perairan laut yang memiliki berbagai jenis potensi hasil laut, yaitu ikan cakalang (Katsuwonus pelamis), ikan tuna (Thunnus Sp), layang (Decapterus russeli), Tongkol (Eutynnus Sp), teri (Stolephorus Sp) 
dan nike (belum ada nama ilmiah). Terdapat juga berbagai ikan pelagis kecil dan demersal yang memiliki potensi ekonomi yang cukup tinggi di wilayah perairan Gorontalo. Hasil tangkapan ikan pelagis besar sebanyak 1.550 ton/tahun dan untuk ikan tuna produksi pada Tahun 2016 adalah $554.137 \mathrm{Kg}$, ikan pelagis kecil 5.394 ton/tahun dan ikan demersal sebanyak 5.456 ton/tahun. Peluang saat ini yaitu Pemerintah di Provinsi Gorontalo menargetkan volume produksi olahan hasil perikanan tahun ini mencapai $9.946 .321 \mathrm{~kg}$ dan tahun depan mematok $10.997 .943 \mathrm{~kg}$. Produksi perikanan laut Provinsi Gorontalo saat ini menjadi terbesar ke-24 di Indonesia, dengan total produksi tahun sebesar 104.437 Ton. Angka ini mengalami kenaikan tiap tahun dari Tahun $2000-2015$. Pemerintah melalui Kementerian Perikanan dan kelautanmenetapkan bahwa ikan tuna menjadi potensi besar dengan kualitas tinggi sebagai potensi perikanan dalam menopang perekonomian Gorontalo. Akan tetapi, saat ini produksi tuna hasil tangkapan nelayan di Gorontalo hanya dikirim antar pulau ke sejumlah daerah seperti Makassar, Surabaya, Jakarta, dan Bali. Mengingat potensi perikanan Gorontalo sangat baik di buktikan dengan banyaknya permintaan dari daerah tetangga. Sehingga ini pun menjadi potensi yang besar untuk Provinsi Gorontalo melakukan ekspor ke luar negeri.

Kementerian Perikanan dan kelautan sudah menjanjikan mulai 2016 produksi perikanan ikan tuna hasil tangkapan nelayan dari Gorontalo akan dikirim ke berbagai negara. Namun, hingga saat ini Provinsi Gorontalo belum melakukan ekspor keluar negeri sebagai tambahan pendapatan nelayan di Provinsi Gorontalo. Hal ini harus segera di benahi mengingat potensi yang Provinsi Gorontalo miliki sangat besar dan bisa meningkatkan ekonomi Gorontalo. Oleh karena itu, penting untuk mengetahui daya saing ikan tuna (Thunnus Sp.) dan strategi pengembangan yang dapat dilakukan untuk mendukung daya saing yang dimiliki.

Provinsi Gorontalo memiliki potensi kelautan dan perikanan yang cukup besar terutama dalam pengembangan usaha perikanan tangkap tuna. Namun kondisi potensi yang menjanjikan ini, belum diikuti dengan pengelolaan dan pemanfaatan yang baik. Untuk itu sangat penting mengetahui bagaimana daya saing dan strategi pengembangan sektor perikanan tuna di Provinsi Gorontalo dalam peningkatan berbagai sektor untuk ke arah yang lebih baik.

\section{METODE}

Penelitian ini akan dilaksanakan di Provinsi Gorontalo, dan dimulai pada bulan Agustus 2017 sampai dengan bulan Februari tahun 2018. Jenis data penelitian adalah data primer dan data sekunder. Data sekunder diperoleh dari hasil penelitian terdahulu, dan berbagai literatur baik dari media massa maupun media elektronik (internet) yang relevan dengan masalah yang diangkat serta dapat dipertanggung jawabkan. Data penunjang diperoleh dari badan informasi yang mendukung dari instans-instansi yang terkait seperti Badan Pusat Statistik (BPS), Provinsi Gorontalo dalam Angka, DKP Provinsin Gorontalo, Balai karantina Ikan di Provinsi Gorontalo. Bentuk data ini terdiri dari data time series 5-10 tahun dan data cross section.

Pengumpulan data tahap I dimulai sejak bulan Agustus 2017 berupa studi literatur, pencarian data statistik, serta browsing internet, sedangkan pengumpulan data tahap II dilakukan pada bulan September-Oktober 2017. Pada tahap II ini pengumpulan data dilakukan dengan wawancara mendalam dengan tokoh perikanan nasional (indept interview). Wawancara dilakukan dengan beberapa narasumber yang dinilai mampu mewakili beberapa komponen penting dalam hal perikanan khususnya tuna di Gorontalo. Beberapa narasumber dalam penelitian ini adalah Mantan Menteri Perikanan dan Kelautan Republik Indonesia Periode 2001-2004, Kepala Bidang Perikanan Budidaya Provinsi Gorontalo, Wakil dekan 1 Fakultas Perikanan dan Kelautan UNG, Nelayan dan pemilik pabrik Pembekuan Ikan.

Metode analisis data yang digunakan dalam penelitian ini adalah analisis kecenderungan dengan menggunakan metode garis trend secara bebas (Free Hand 
Method). Metode trend dengan metode bebas ini dilakukan dengan mengamati sebaran data bisa sehingga diketahui kecenderungan garis trend dari pola data tersebut dari perhitungan nilai RCA. Rumus yang digunakan adalah sebagai berikut (Yunia, 2015: 14):

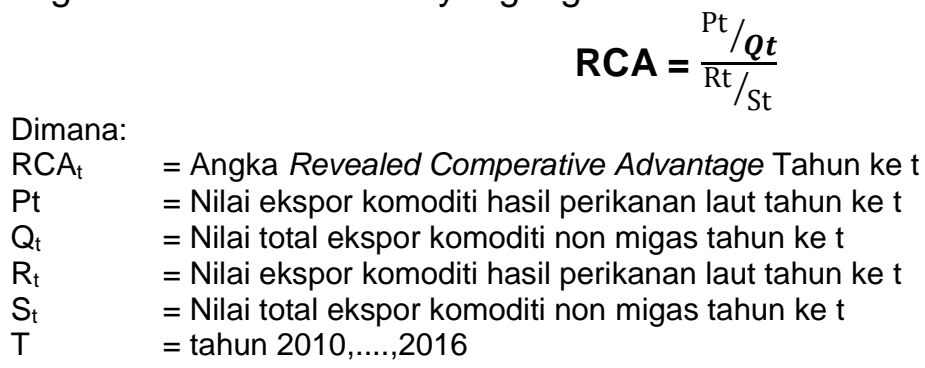

Jika nilai RCA $>1$ maka Memiliki Keunggulan; dan jika nilai $\mathrm{RCA}<1$ maka tidak memiliki keunggulan (Salvatore, 1997 dalam Cahya, 2010: 41).

Nilai indeks RCA berkisar antara nol sampai tak hingga. Nilai indeks RCA sama dengan satu berarti tidak terjadi kenaikan RCA atau kinerja ekspor Hasil Perikanan Provinsi Gorontalo tidak berupa dari tahun sebelumnya (Pratama, 2015). Jika nilai indeks RCA lebih kecil dari satu berarti terjadi penurunan kinerja ekspor komoditi hasil perikanan laut Sedangkan jika nilai indeks RCA lebih besar dari satu maka kinerja ekspor Komoditi hasil perikanan laut lebih tinggi dari tahun sebelumnya. Rumus yang digunakan adalah sebagai berikut :

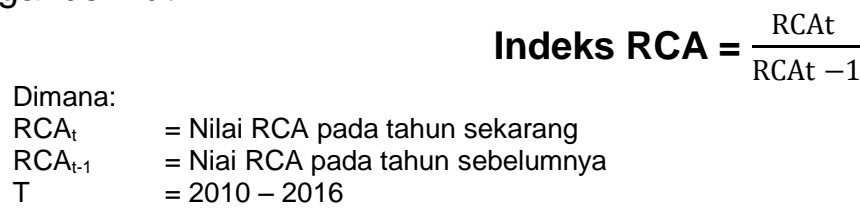

Alat analisis yang digunakan untuk menyusun formulasi strategis tersebut adalah matriks SWOT. Matriks ini menggambarkan secara jelas bagaimana peluang dan ancaman dapat disesuaikan dengan kekuatan dan kelemahan yang dimiliki. Matriks ini dapat menghasilkan empat sel kemungkinan alternatif strategi (Damelia, 2015).

\section{HASIL DAN PEMBAHASAN}

\section{Kecenderungan Lalulintas Ikan Tuna Provinsi Gorontalo}

Ikan tuna termasuk dalam family scombriadea, hidup diperairan lepas pantai, laut dalam dan berkadar garam tinggi. Di Provinsi Gorontalo tuna merupakan salah satu yang memiliki nilai ekonomis penting dan sangat tinggi ynilai harganya. Ikan tuna di Provinsi Gorontalo memiliki kualitas yang baik, hal ini sejalan dengan penilaian para wisatawan yang datang berkunjung ke Gorontalo. Namun, hingga saat ini Gorontalo belum melakukan ekspor secara langsung melainkan hanya melakukan pengiriman antar pulau, dan nantinya akan di kumpulkan di suatu daerah untuk di ekspor keluar.

Tabel 1 Volume Produksi Jenis Jenis Ikan Tuna

\begin{tabular}{|c|c|c|c|c|c|c|c|c|}
\hline \multirow{2}{*}{ NO } & \multirow{2}{*}{$\begin{array}{l}\text { JENIS } \\
\text { KOMODITI }\end{array}$} & \multicolumn{6}{|c|}{ VOLUME (Kg) } & \multirow{2}{*}{ Keterangan } \\
\hline & & $2017^{*}$ & 2016 & 2015 & 2014 & 2013 & 2012 & \\
\hline 1 & Ikan Tuna & 337.537 & 554.137 & 418.446 & 430.107 & 397.658 & 330.777 & Utuh dan Loin \\
\hline 2 & Baby Tuna & 26.628 & 4.084 & 0 & 0 & 0 & 0 & \\
\hline 3 & Ikan Cakalang & 47.398 & 9.268 & 39 & 83.643 & 0 & 195.017 & \\
\hline 4 & Ikan Tongkol & 252.764 & 478.617 & 63.793 & 389.745 & 6.500 & 0 & \\
\hline 5 & Ikan Kembung & 41.082 & 20.436 & 216 & 4.530 & 0 & 0 & \\
\hline 6 & Ikan Selar & 5.750 & 22 & 0 & 10,150 & 0 & 0 & \\
\hline 7 & Ikan Layang & 278.305 & 334.119 & 262.606 & 91.752 & 0 & 0 & \\
\hline
\end{tabular}

Pada tahun 2016 total ekspor ikan tuna Indonesia mencapai 872.744 Ton. Hasil ini tentu menunjukkan peningkatan pesat dari lima tahun sebelumnya dimana di tahun 2012 
sebesar 51.508 Ton. Sedangkan Gorontalo mampu mengirim ikan tuna antar pulau pada tahun 2012 sebesar 330 Ton atau $0.64 \%$ dari total ekspor Indonesia.

Info dari PDS (Ditjen penguatan daya saing produk kelautan dan perikanan), harga tuna grade I di tingkat nelayan itu Rp 50 ribu per $\mathrm{kg}$. Grade II Rp 35 ribu per kg, grade III $\mathrm{Rp} 20$ ribu per $\mathrm{kg}$. Jadi seandainya kita tangkap grade 1 lebih banyak, maka jumlah yang dibawa bisa lebih banyak dalam jumlah tangkapan yang sama dengan grade 3 pada November 2017. Namun, harga ini makin meningkat menjadi Rp. 75 ribu / Kg untuk Grade 1. Tentunya hal ini menjadi satu peluang untuk para nelayan dan pengumpul untuk bisa mengirim dan memproduksi lebih banyak lagi, dalam memenuhi permintaan pasar. Karena, dari tahun ke tahun mengalami peningkatan untuk permintaan perdagangan antar pulau.

Nelayan Gorontalo sering mengeluhkan beberapa hal yang menghambat produksi ikan tuna ataupun penangkapan atau melaut karenas susah didapatkannya pasokan es untuk melatu dan susahnya mendapatkan BBM saat ingin melaut. Karena pemasok dari luar daerah Gorontalo sudah tau betul akan kualitas ikan tuna Gorontalo. Sehingga yang menentukan tingginya angka lalu lintas ikan tuna Gorontalo adalah Produksi ikan tunanya. Oleh karena itu, peran pemerintah berupa kebijakan dan bantuan yang paling dibutuhkan oleh semua pihak untuk peningkatan hasil produksi ikan tuna Provinsi Gorontalo.

\section{Tren Produksi Ikan Tuna Provinsi Gorontalo}

Perkembangan produksi ikan tuna Provinsi Gorontalo harus tinggi, namun dalam grafik di bawah kita masih bisa melihat produksi dari tahun 2011 - 2016 mengalami fluktuasi atau turun naik. Sebaiknya pemerintah tetap memperhatikan berbagai aspek atau faktor yang menghambat dan membuatn produksi menurun. Contohnya adalah faktor internal berupa tidak ada jaminan nelayan bisa berkembang dan sejahtera sehingga jumlah nelayan pun akan semakin berkurang, faktor iklim juga sebagai penentu dalam hasil produksi ikan Tuna. Selain itu, kurangnya pengusaha yang mampu mengirim keluar dan tidak adanya mitra kerja di luar negeri adalah salah satu yang menghambat nelayan masih kurang sejahtera.

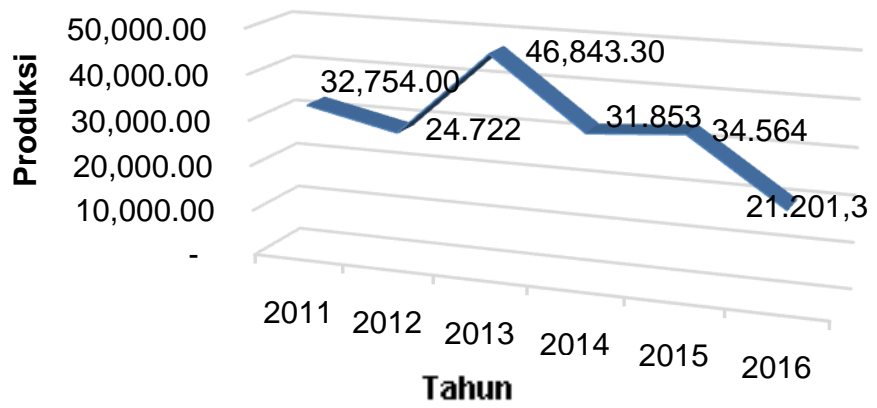

Gambar 1 Grafik Perkembangan Produksi Ikan Tuna Provinsi Gorontalo Sumber: Data DKP, diolah 2017

Untuk produksi ikan tuna di Provinsi Gorontalo pada tahun 2011 berjumlah 32.754 ton, dari grafik di atas jumlah produksi mengalami fluktuasi, yaitu pada tahun 2013 produksi tuna jenis madidihang adalah yang paling tinggi berjumlah 46.843,3 Ton dan terendah adalah 2016 adalah 21.201,3 Ton. Dengan melihat jumlah produksi ikan tuna jenis madidihang yang menurun yaitu dari 34.564 ton di tahun 2015, menurun menjadi $21.201,3$ ton di tahun 2016. Selain itu, hal ini dipengaruhi oleh berbagaia faktor internal maupun ke faktor eksternal, yaitu dari iklim, cuaca, hingga peralihan pekerjaan.

\section{Daya Saing Ikan Tuna Provinsi Gorontalo}

RCA digunakan untuk membandingkan posisi daya saing Gorontalo dengan daerah produsen lainnya di pasar ikan tuna internasional. Jika RCA sama dengan satu, berarti 
daya saing komoditas tersebut sama dengan daerah lain yang terlibat dalam kegiatan ekspor komoditas tersebut.

Tabel 2 Total Perdagangan Ikan Tuna dan Perdagangan Non-migas Gorontalo

\begin{tabular}{ccr}
\hline Tahun & $\begin{array}{c}\text { Nilai Perdagangan Ikan Tuna } \\
\text { (Juta US \$) }\end{array}$ & $\begin{array}{c}\text { Nilai Ekspor Non Migas } \\
\text { (US\$) }\end{array}$ \\
\hline 2012 & 2,43 & 14.200 .000 \\
2013 & 2,31 & 5.200 .000 \\
2014 & 3,61 & 15.100 .000 \\
2015 & 2,56 & 31.381 .776 \\
2016 & 4,34 & 4.300 .000 \\
2017 & 2,72 & 1.600 .000 \\
\hline Sumber: BPS Provinsi Gorontalo, 2018
\end{tabular}

Nilai perdagangan ikan tuna Gorontalo mengalami fluktuasi, mulai dari tahun 2012 pada angka USD $\$ 2.433 .374,62$ dan pada tahun 2013 mengalai penurunan menjadi USD\$2.309.180,77. Tahun selanjutnya pada tahun 2014 mengalami kenaikan yang cukup tinggi mencapai 56\% yaitu pada nilai USD\$3.605.990,77. Pada tahun 2016 adalah perdagangan tertinggi dari rentang waktu 2012-2017 yaitu dengan nilai USD\$ 4.335.821,92. danuntuk nilai ekspor non migas lebih cenderung berfluktuasi atau menglami kenaikan dan penurunan di tiap tahun selama 2012-2017. Dengan nilai ekspor non migas Gorontalo tertinggi ada pada tahun 2015 yaitu sebesar USD\$31.381.776 dan mengalami penurunan pada tahun 2017 sebesar USD\$ 4.308.303 hal ini mengalami penurunan yang sangat tinggi mencapai $728 \%$. Dan pada 2017 mengalami penurunan sebesar USD\$2.700.000. Hal ini tentu di harapkan untuk terus meningkat lagi, dalam menambah atau meningkatkan ekonomi Gorontalo dan tentunya dengan visi untuk mensejahterakan rakyat.

Tabel 3 Total Perdagangan Ikan Tuna dan Perdagangan Non-migas Gorontalo

\begin{tabular}{|c|c|r|r|r|r|r|}
\hline Tahun & $\begin{array}{c}\text { Perdagangan } \\
\text { Ikan Tuna } \\
\text { (Juta US \$) }\end{array}$ & $\begin{array}{c}\text { Nilai Ekspor } \\
\text { Non Migas } \\
\text { (US\$) }\end{array}$ & $\begin{array}{c}\text { Nilai Hasil } \\
\text { Ekspor Ikan } \\
\text { Tuna } \\
\text { Indonesia } \\
\text { (Juta US\$) }\end{array}$ & $\begin{array}{c}\text { Nilai Ekspor } \\
\text { Non Migas } \\
\text { (Juta US\$) }\end{array}$ & RCAT & Keterangan \\
\hline 2012 & 2,43 & 14.200 .000 & 314,50 & $153.043,00$ & 83,39 & Memilki Keunggulan \\
\hline 2013 & 2,31 & 5.200 .000 & 312,60 & $149.918,80$ & 212,97 & Memilki Keunggulan \\
\hline 2014 & 3,61 & 15.100 .000 & 234,13 & $145.961,20$ & 143,37 & Memilki Keunggulan \\
\hline 2015 & 2,56 & 31.381 .776 & 202,45 & $131.791,90$ & 53,10 & Memilki Keunggulan \\
\hline 2016 & 4,34 & 4.300 .000 & 174,36 & $132.080,80$ & 763,83 & Memilki Keunggulan \\
\hline 2017 & 2,72 & 1.600 .000 & $4.030,00$ & $139.680,70$ & 232,26 & Memilki Keunggulan \\
\hline
\end{tabular}

Dengan nilai hasil RCA ikan tuna pada tahun 2012 sampai tahun 2017 lebih besar dari satu (>1) bahkan sampai mencapai angka 763 ditahun 2016 maka dapat dikatakan bahwa nilai perdagangan ikan tuna Gorontalo memiliki keunggulan komparatif dengan daya saing yang kuat. Selain itu, untuk dapat mengetahui kinerja perdagangan ikan tuna Gorontalo dapat dilihat dari perhitungan indeks RCA Ikan Tuna yakni sebagai berikut:

Tabel 4 Indeks RCA

\begin{tabular}{cc}
\hline Tahun & Indeks RCA \\
\hline 2012 & \\
2013 & 1,553906408 \\
2014 & $-0,326825374$ \\
2015 & $-0,629619296$ \\
2016 & 13,38455744 \\
2017 & $-0,695923123$ \\
\hline Sumber: Data diolah, 2018
\end{tabular}


Kecenderungan nilai perdagangan Ikan tuna Gorontalo menunjukkan bahwa nilai indeks RCA lebih dari satu (>1) maka kinerja perdagangan Ikan tuna Gorontalo lebih baik dari sebelumnya. Sedangkan jika kurang dari satu $(<1)$ maka terdapat penurunan kinerja perdagangan dan ekspor Gorontalo. Dari tabel 4, indeks RCA mengalami naik turun. Dari tabel di atas kinerja perdagangan tertinggi berada pada tahun 2016 yaitu angka 13,38. $\mathrm{Hal}$ ini dikarenakan, pada tabel RCA mengalami peningkatan yang signifikan. Sehingga angka indeks RCA juga tinggi. Sebaliknya angka terendah berada pada tahun 2015 yaitu -0,62; hal ini dikarenakan nilai RCA dari tahun 2014 ke tahun 2015 mengalami penurunan yang sangat tinggi. Dari hasil ini dapat diketahui bahwa kinerja perdagangan ikan tuna pada tahun 2016 sangat baik sehingga indeks RCA cukup tinggi dan melebihi angka satu.

\section{Strategi Pengembangan Ikan Tuna Di Provinsi Gorontalo}

Analisis SWOT daya saing ikan tuna Provinsi Gorontalo dalam hasil operasionalnya memiliki kekuatan yang lebih dominan dari kelemahannya dan nilai peluang lebih besar dari ancamannya. Nilai kekuatan sebesar 1,96 dikurangi nilai kelemahan sebesar 1,5 mendapatkan hasil 0,46 dan untuk nilai peluang sebesar 2,17 dikurangi nilai ancaman sebesar 1,26 mendapatkan hasil 0,91. Dengan demikian nilai tersebut dapat dipetakan dalam empat kuadran kurva SWOT seperti di bawah ini:

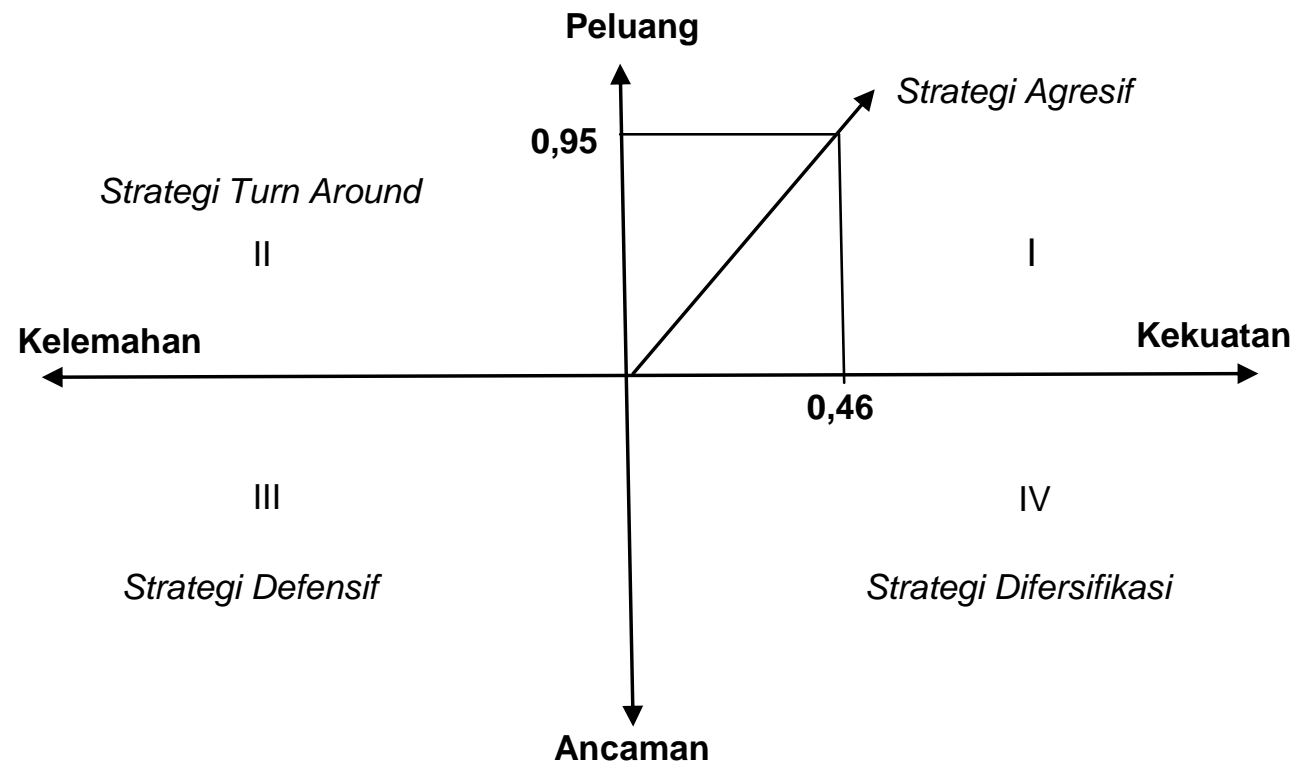

Gambar 2 Kurva SWOT

Sumber: Data diolah 2018

Kurva SWOT di atas menunjukkan kekuatan yang dimiliki lebih besar dari pada kelemahannya, yang menghasilkan sumbu X dalam diagram SWOT. Selain itu, peluang juga lebih besar dari ancaman yang hadapi, sehingga berada pada kuadran 1 dengan nilai 0,95 . Kekuatan yang lebih besar dari kelemahan degan nilai 0,46 membuat garis kekuatan berada pada kuadran 1. Titik pertemuan ini berada pada kuadran strategi agresif. Sehingga jika diartikan strategi agresif yaitu strategi yang situasinya mendukung secara agresif dan sangat baik karena adanya kekuatan yang dimanfaatkan untuk meraih peluang yang menguntungkan. Dengan analisis lebih lanjut daya saing ikan tuna Provinsi Gorontalo, dengan mengidentifikasi kekuatan yang dapat dimanfaatkan sehingga peluang bisa diambil, ancaman terhindar dan kelemahan teratasi. 


\section{SIMPULAN}

Tren produksi dan lalu lintas Ikan Tuna Provinsi Gorontalo mengalami peningkatan dengan beberapa faktor penentu keberhasilannya. Nilai RCA yang unggul ( $>1$ ) dari tahun 2012-2017, menjadikan daya saing Ikan Tuna Provinsi Gorontalo berdaya saing tinggi di pasar nasional. Oleh karenanya itu, dengan strategi pengembangan yang menunjukkan bahwa ikan tuna berada di kuadran 1 (agresif), dimana adanya kekuatan dari daya saing ikan tuna dapat mengambil peluang yang ada untuk mendapatkan keuntungan yang maksimal.

\section{DAFTAR PUSTAKA}

BAPPEDA. 2015. Rencana Pembangunan Jangka Menengah Daerah (RPJMD). Bone Bolango

Badan Pusat Statistik. 2017. Gorontalo dalam Angka 2017. Gorontalo

Cahya, I. N., 2010. Analisis Daya Saing Ikan Tuna Indonesia Di Pasar Internasional. Skripsi. Institut Pertanian Bogor, Bogor

Damelia, D., 2015. Analisis Daya Saing Dan Strategi Peningkatan Rumput Laut Indonesia. Skripsi. Universitas Negeri Semarang, Semarang

Daryanto, Arief. 2007. Dari Klaster Menuju Peningkatan Daya Saing Industri Perikanan. Buletin Craby \& Starky, Edisi Januari 2007

Darsono, P.1999. Pemanfaatan Sumber Daya Laut Dan Implikasinya Bagi Masyarakat Nelayan. Jurnal Oseana, 9.

Johan Van Rooyen \& Johann Boonzaaier, 2016. Competitiveness In The Agribusiness Environment (From Analysis To Cooperative Strategy Development - A South Africa Case Study). Pp. 1

Pratama, W., 2015. Analisis Daya Saing Kedelai Indonesia. Skripsi. Universitas Negeri Semarang, Semarang

Wahyuni, S., 2011. Histamin Tuna (Thunnus Sp) Dan Identifikasi Bakteri Pembentukannya Pada Kondisi Suhu Penyimpanan Standar. Skripsi. Institut Pertanian Bogor, Bogor

Yunia, S. N., 2015. Analsis Daya Saing Dan Faktor-Faktor Yang Mempengaruhi Ekspor Alas Kaki Di Indonesia.Skripsi. Institut Pertanian Bogor. Bogor 